\title{
First bird footprints from the lower Miocene Lerín Formation, Ebro Basin, Spain
}

\author{
Ignacio Díaz-Martínez, Oier Suarez-Hernando, \\ Blanca María Martínez-García, Juan Cruz Larrasoaña, and Xabier Murelaga
}

\begin{abstract}
A new tracksite with bird footprints, found in the Bardenas Reales de Navarra Natural Park (Navarre, Spain), is presented in this study. The footprints are preserved in four sandstone blocks of the Lerín Formation from the northwest sector of the Ebro Basin. According to the magnetostratigraphic data, the age of these blocks is $20.4 \mathrm{Ma}$ (Agenian, lower Miocene). The footprints are more than $100 \mathrm{~mm}$ in length, mesaxonic, and tridactyl, and have a prominent central pad impression with the digit impressions not jointed proximally. These features allow classifying them as Uvaichnites riojana. Some of the studied footprints are better preserved than the type series of Uvaichnites, which were found also in the northwest sector of the Ebro Basin. Therefore, the original diagnosis has been emended. Available chronostratigraphic data for these localities as well as for other footprints from China indicate a latest Oligocene-earliest Miocene age (from about 23 to $20 \mathrm{Ma}$ ) for Uvaichnites-like footprints. Sedimentological data also indicate similar continental environments, namely perilacustrine deltaic systems and distal alluvial systems. The information about early Miocene avian remains (bones, eggs and footprints) in the Iberian Peninsula is scarce. The skeletal and oological record of this age has been included within the families Phoenicopteridae, Phaisanidae and Cathartidae (or incertae sedis), while the ichnological record was related with trackmakers belonging to Charadriiformes, Ardeidae and Gruidae taxa. For this scenario, in which there are few avian remains, the ichnological diversity shown in this paper complements and improves the knowledge about the Iberian avian diversity in the early Miocene.
\end{abstract}

Ignacio Díaz-Martínez CONICET - Instituto de Investigación en Paleobiología y Geología, Universidad Nacional de Río Negro, General Roca 1242, 8332 Fisque Menuco (General Roca), Río Negro, Argentina. inaportu@hotmail.com

Oier Suarez-Hernando Universidad del País Vasco UPV/EHU, Facultad de Ciencia y Tecnología, Departamento de Estratigrafía y Paleontología, Apartado 644, E-48080 Bilbao, Bizkaia, Spain.

oier.suarez@ehu.eus

Blanca María Martínez-García Universidad del País Vasco UPV/EHU, Facultad de Ciencia y Tecnología, Departamento de Estratigrafía y Paleontología, Apartado 644, E-48080 Bilbao, Bizkaia, Spain. blancamaria.martinez@ehu.eus

Díaz-Martínez, Ignacio, Suarez-Hernando, Oier, Martínez-García, Blanca María, Larrasoaña, Juan Cruz, and Murelaga, Xabier. 2016. First bird footprints from the lower Miocene Lerín Formation, Ebro Basin, Spain. Palaeontologia Electronica 19.1.7A: 1-15 palaeo-electronica.org/content/2016/1417-early-miocene-bird-footprints 
Juan Cruz Larrasoaña Instituto Geológico y Minero de España, Unidad de Zaragoza, 50006 Zaragoza, Spain. Now Visiting Scientist at Institute of Earth Sciences Jaume Almera, ICTJA-CSIC, 08028 Barcelona, Spain. jc.larra@igme.es

Xabier Murelaga Universidad del País Vasco UPV/EHU, Facultad de Ciencia y Tecnología, Departamento de Estratigrafía y Paleontología, Apartado 644, E-48080 Bilbao, Bizkaia, Spain. xabier.murelaga@ehu.eus

Key words: bird footprints; Uvaichnites riojana; early Miocene; Lerín Formation; Ebro Basin; avian diversity Submission: 15 October 2015 Acceptance: 20 January 2016

\section{INTRODUCTION}

In the last 20 years, different studies in the northwestern part of the continental Ebro Basin (Figure 1) have reported a wealth of novel Cenozoic paleoichnological data (see Díaz-Martínez et al., 2011, 2015; and references herein). The oldest avian footprints, Eocene in age, are from Javier and Liédena (Navarra province), where the ichnotaxon Leptoptilostipus pyrenaicus has been described (Payros et al., 2000). In the Oligocene, artiodactyl, perissodactyl, and bird tracks have been found in Olkotz, Olejua and Etaio, also in the Navarra province (Astibia et al., 1994; Murelaga et al., 2000, 2007). Oligocene to Miocene deposits from Alcanadre (La Rioja province) have provided also several bird footprints (García-Raguel et al., 2009). Of special relevance is the lower Miocene ichnological record due to its diversity and abundance. Different morphotypes of perissodactyl, artiodactyl, carnivorous, and bird tracks have been identified in the Navarra (Desojo and Los Arcos localities) and La Rioja provinces (Cenicero and Logroño localities) (López et al., 1992; Astibia et al., 2007; Díaz-Martínez et al., 2011, 2012, 2015). In addition, in Cenicero locality, the avian ichnotaxon Uvaichnites riojana Díaz-Martínez et al. (2012) has been defined for the first time.

Recently, we were informed by a shepherd about the presence of some sandstone blocks with bird footprints close to the Aguilares zone within the Bardenas Reales de Navarra Natural Park (Navarra province, northwest sector of the Ebro Basin). Although several vertebrate remains have been found in this Natural Park (see Murelaga, 2000), this is the first record of vertebrate tracks in the area. The blocks with bird footprints were transported to the Aguilares Information Center of Bardenas Reales to be protected, studied, and exposed. The main aim of this work is to describe in detail these new bird footprints and to discuss their ichnotaxonomical and paleobiological implications. To do so, we have compared these remains with other early Miocene avian ichnological, osteo- logical, and oological records in the Iberian Peninsula, to have an integrated view of the avian paleodiversity for this time period in the peninsula.

\section{GEOLOGICAL SETTING}

The Aguilares tracksite (Figure 1.1) is located in the Cenozoic Ebro Basin, a large foreland basin filled with more than $4,000 \mathrm{~m}$ of Oligocene-Miocene continental deposits (Villena et al., 1996). The Ebro Basin is an endorreic basin that formed at the foothills of the Pyrenees, the Iberian Range and the Catalan Coastal Ranges fold-and-thrust belts (Villena et al., 1996). Bardenas Reales de Navarra Natural Park is a semiarid steppe region located close to the vicinity of Tudela, in the central sector of the western part of the Ebro Basin (Larrasoaña et al., 2006). In this area, the distal fluvial, palustrine and lacustrine sediments of the lower Miocene Lerín and Tudela Formations crop up extensively (Figure 1.2).

The footprints have been found in fine-grained sandstones blocks of the Lerín Formation. The outcropping sediments of the Lerín Formation are composed of about $20 \mathrm{~m}$ of reddish and brown mudstones that include common grey, thin $(\mathrm{cm}$ to $\mathrm{dm}$ ) sheet-like sandstone intercalations, and are overlain by about $20 \mathrm{~m}$ of ochre and yellow mudstones with laminated and nodular gypsum beds that form two main levels (Larrasoaña et al., 2006). The Lerín Formation can be included into the tectosedimentary unit (TSU) 4 of Alonso-Zarza et al. (2002), and represents the deposition in a distal alluvial-saline lacustrine system developed at the central part of the basin during the late Oligocene and early Miocene (Muñoz-Jiménez and CasasSainz, 1997; Ingles et al., 1998). Up to this study, no fossil remains had been reported from the Lerín Formation.

The blocks with bird footprints appeared "ex situ" on a farmland. It has been estimated that these blocks had been eroded from a nearby outcrop (no more than $50 \mathrm{~m}$ away), which consists of red or orange mudstones interbedded with sand- 

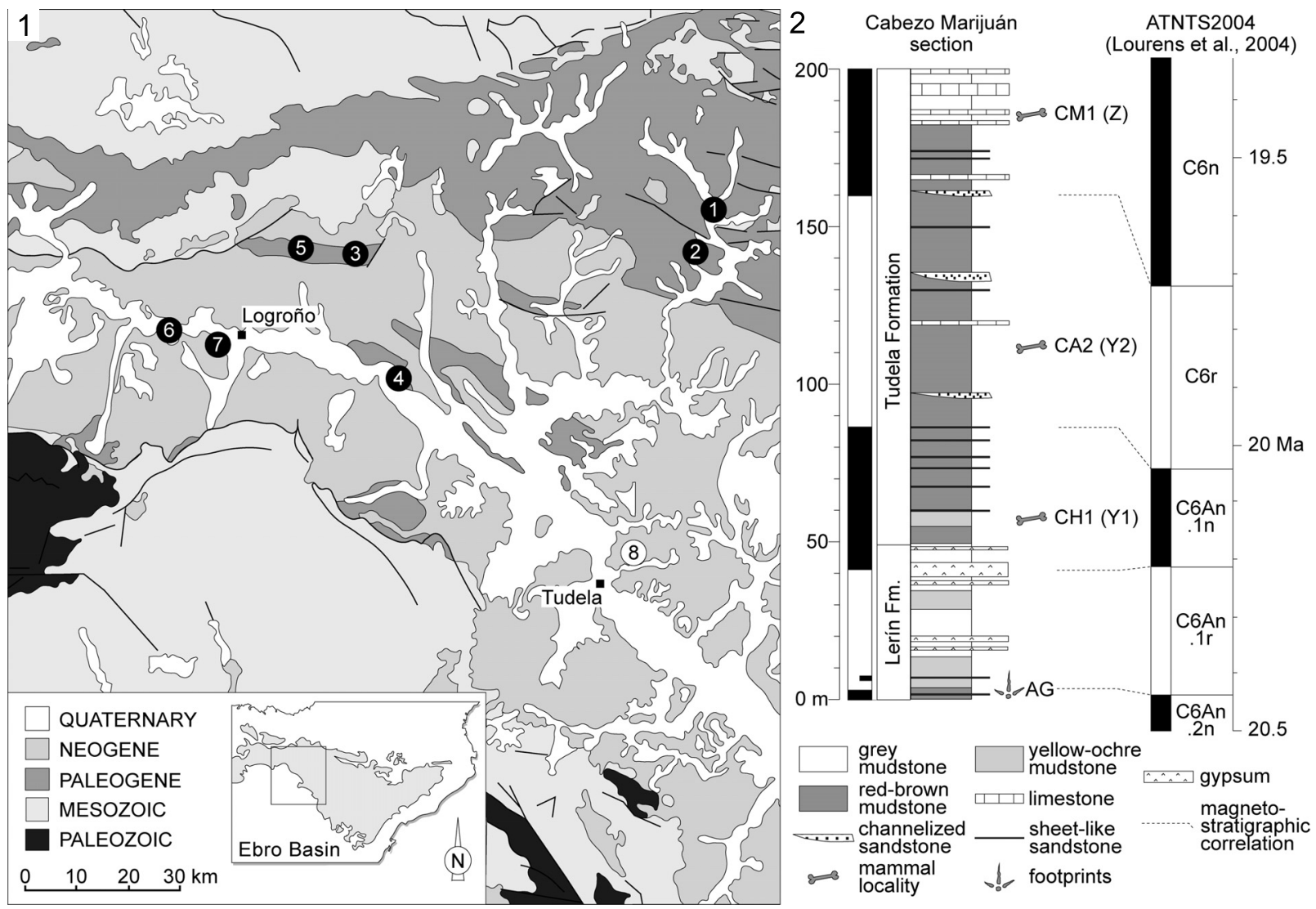

FIGURE 1. 1, Locality map for the Aguilares tracksite and the other tracksites with vertebrate footprints in the western area of the Ebro Basin: 1, Javier-Liédena; 2, Olejua; 3, Olkotz-Etaio; 4, Alcanadre; 5, Desojo-Los Arcos; 6, Cenicero; 7, Logroño; 8, Aguilares. 2, Composite lithostratigraphic and magnetostratigraphic logs of the Cabezo Marijuán stratigraphic section (see Larrasoaña et al., 2006) and their correlation to the ATNTS2004 of Lourens et al. (2004). The position of Aguilares tracksite is described in this study; for the other fossil localities see Murelaga (2000) and see Ruiz-Sánchez et al. (2012).

stones in layers less than $30 \mathrm{~cm}$ thick. This facies assemblage suggests sedimentation in a distal alluvial, mud-dominated floodplain related with the margin of the saline lacustrine system, where the sandstones correspond with the infill of small paleochannels by low-energy currents. The absence of micromammal fossils on the section that contains the sandstone blocks with avian footprints prevents a biostratigraphic date of them. For that reason, a litho-stratigraphical correlation has been done between the studied section and the Cabezo Marijuán section (see Ruiz-Sánchez et al., 2012), for which paleontological and paleomagnetic age constrains are available (Figure 1.2). Based on the facies assemblage and the presence of fine gypsum levels at the top of the studied section, the sandstone blocks with footprints can be correlated with the lower part of Cabezo Marijuán section within the upper part of Lerín Formation. According to the magnetobiostratigraphic data of this section (Larrasoaña et al., 2006; Ruiz-Sánchez et al., 2012), we estimate an age of about $20.4 \mathrm{Ma}$ (Agenian, lower Miocene) for the footprints.

\section{MATERIAL AND METHODS}

This work studies four blocks with 12 avian footprints that are preserved as convex hyporeliefs (natural casts) without clear erosional structures. The footprints used here for the analysis are: AG11, AG1-2, AG1-3, AG2-1.1, AG2-1.2, AG3-1.1, AG3-1.2, AG3-2, AG3-3, AG3-4, AG4-1, and AG42 (Figure 2.1-4). The footprints are designated according to previous convention (e.g., Casanovas et al., 1989; Pérez-Lorente, 2001) as follows: first, the tracksite identification; second, the block; and third, the trackway and the footprint. For instance, AG3-1.1 is the first footprint of the trackway number 1 identified in the block 3 of Aguilares (AG) tracksite. The footprints are preserved in four sandstone blocks curated in the Aguilares Information 
1
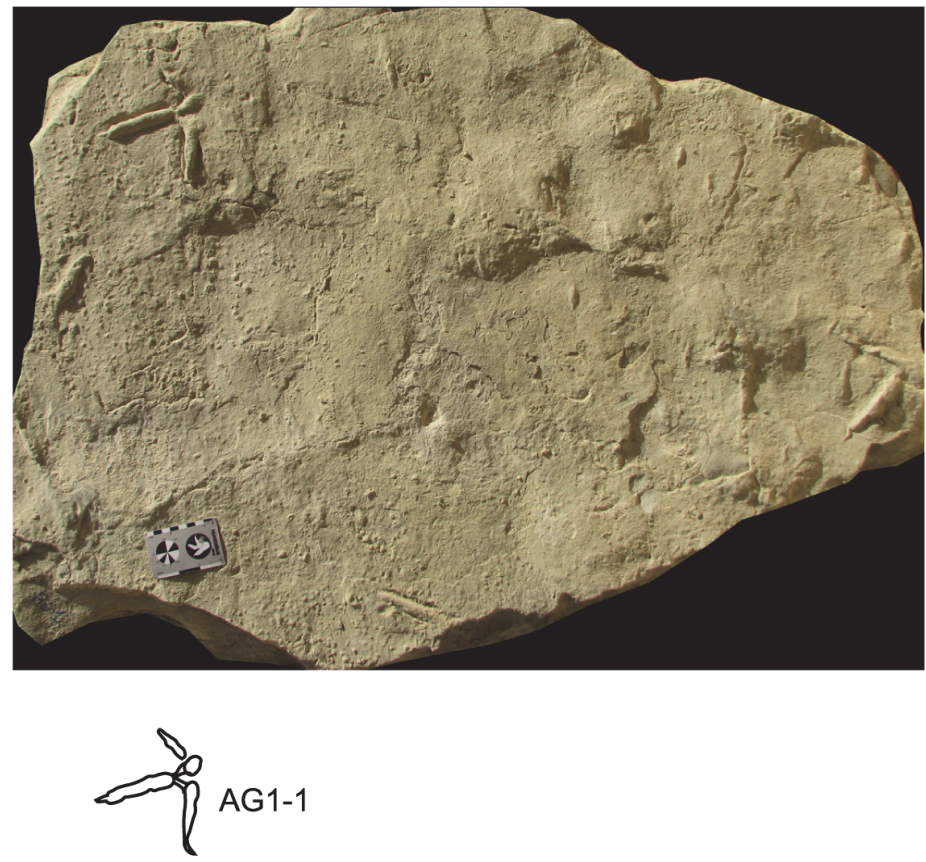

2
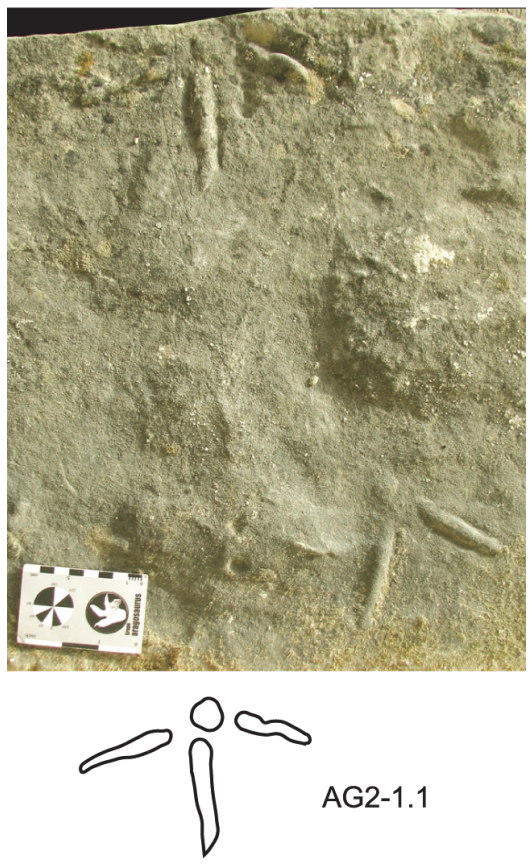

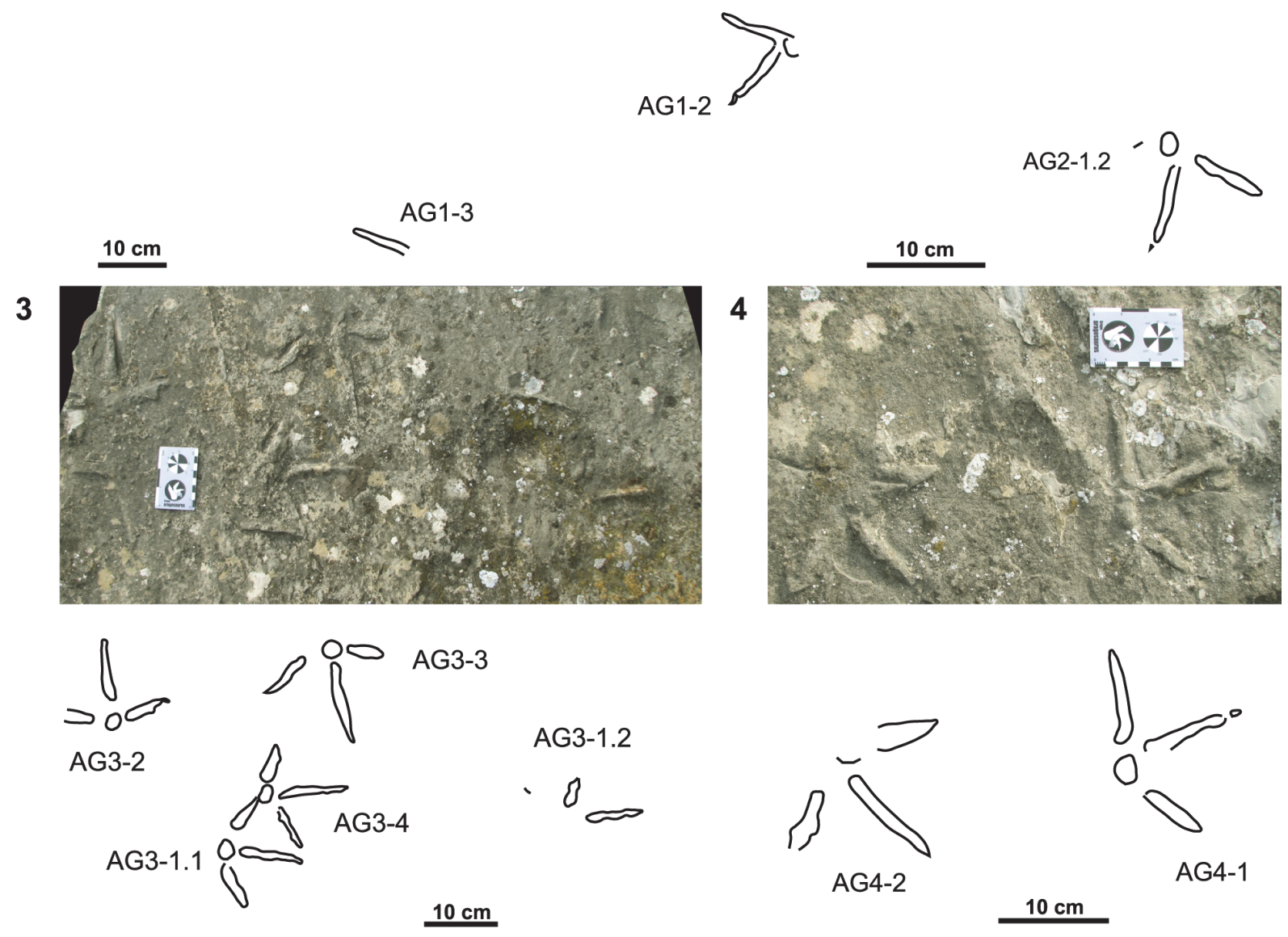

FIGURE 2. Photographs and sketches of the blocks of the Aguilares bird footprints. 1, AG1 block; 2, AG2 block; 3 , AG3 block; 4, AG4 block. 
Center of Bardenas Reales de Navarra Natural Park (Comunidad de Bardenas Reales, Navarra, Spain).

The measurements (Table 1) and the nomenclature used in this study are mainly based on previous works (Pérez-Lorente, 2001; de Valais and Melchor, 2008; Díaz-Martínez et al., 2011). The measurements taken include: footprint length (FL), footprint width (FW), central pad length and width (cpLxW), digit II length (II), digit III length (III), digit IV length (IV), angle between digits II and III (II^III), angle between digits III and IV (III^IV), angle between digits II and IV (II^IV), and pace length (PL).

All parameters are given and compared in millimeters, except for II^III, II^^IV, and I^^IV, which are in degrees. The ichnotaxonomic analysis is based on the ichnotaxobases proposed by de Valais and Melchor (2008) and Díaz-Martínez et al. (2011).

The photogrammetric images (Falkingham, 2012; Mallison and Wings, 2014) (Figure 3.1-6) were obtained using Agisoft PhotoScanTM (version 0.8.5.1423) software (Grupo Aragosaurus, Universidad de Zaragoza License) for the holotype of Uvaichnites riojana and one footprint of $A G$ (AG1-1) (see Appendix 1, Appendix 2) with the aim of studying the track morphology through depth maps and contour lines. Photogrammetric models were also imported into MeshlabTM (meshlab.sourceforge.net/) for scaling and ParaviewTM (www.paraview.org/) to generate false-color depth maps and contour lines.

\section{SYSTEMATIC ICHNOLOGY}

ICHNOGENUS Uvaichnites Díaz-Martínez, Hernández, García Fernández, Murelaga and Pérez-Lorente, 2012

Type Ichnospecies. Uvaichnites riojana DíazMartínez, Hernández, García Fernández, Murelaga and Pérez-Lorente, 2012

Distribution. Transition unit between the Nájera and Haro Formations of Agenian age (lower Miocene), La Rioja Province, Spain (Díaz-Martínez et al., 2012), and the Lerín Formation of Agenian age (lower Miocene), Navarra Province, Spain (in this work).

Emended diagnosis. Very large to enormous (more than $100 \mathrm{~mm}$ long) mesaxonic tridactyl bird tracks with a prominent central pad and not proximally jointed digits. Total interdigital span is large (more than $100^{\circ}$ ). Angular asymmetry (angle between digits II and III smaller than between III and IV). Web trace absent. Slender digit impressions with well-defined claw marks when they are preserved. Central digit impression (III) is the longest. Digit II is smaller than digit IV. Two digital pad impressions on digits II and IV and three on digit III. Remarks. The bird footprints of Aguilares are undoubtedly belonging to Uvaichnites. They are better preserved than the type series of Uvaichnites riojana and differ in three features from Uvaichnites original diagnosis (see below). Therefore, the original diagnosis of $U$. riojana is emended here with new data of well-preserved bird

TABLE 1. Measurements of the bird footprints of Lerín Formation. Abbreviations: FL, footprint length; FW, footprint width; cpLxW, central pad length and width; II, digit II length; III, digit III length; IV, digit IV length; II^III, angle between digits II and III; III^IV, angle between digits III and IV; I^^IV, angle between digits II and IV; PL, pace length. All parameters are given and compared in millimeters, except for II^III, II^IV, and II^IV, which are in degrees.

\begin{tabular}{lcccccccccc}
\hline & FL & FW & cpLxW & II & III & IV & II^III & III^IV & II^IV & PL \\
\hline AG1-1 & 136 & 174 & $30 \times 20$ & 62 & 94 & 80 & 60 & 66 & 126 & - \\
AG1-2 & 130 & - & $25 \times-$ & - & 98 & 80 & - & 70 & - & - \\
AG1-3 & - & - & - & - & - & - & - & - & - & - \\
AG2-1.1 & 121 & 164 & $25 \times 25$ & 58 & 90 & 70 & 68 & 70 & 138 & - \\
AG2-1.2 & 120 & - & $25 \times 20$ & - & 90 & 78 & - & 76 & - & 400 \\
AG3-1.1 & 123 & 157 & $24 \times 28$ & 50 & 92 & 72 & 58 & 58 & 116 & - \\
AG3-1.2 & 124 & - & - & 44 & 86 & - & 58 & - & - & 470 \\
AG3-2 & 154 & 178 & $28 \times 30$ & 55 & 112 & 78 & 74 & 76 & 150 & - \\
AG3-3 & 140 & - & $25 \times 26$ & 66 & 95 & - & 63 & 63 & 126 & - \\
AG3-4 & 124 & 156 & $20 \times 22$ & 55 & 94 & 70 & 61 & 67 & 128 & - \\
AG4-1 & 125 & 190 & $20 \times 25$ & 65 & 92 & 82 & 58 & 78 & 136 & - \\
AG4-2 & - & 172 & - & 60 & 100 & - & 59 & 72 & 131 & - \\
Mean & 130 & 170 & $25 \times 25$ & 57 & 95 & 76 & 62 & 70 & 131 & - \\
\hline
\end{tabular}



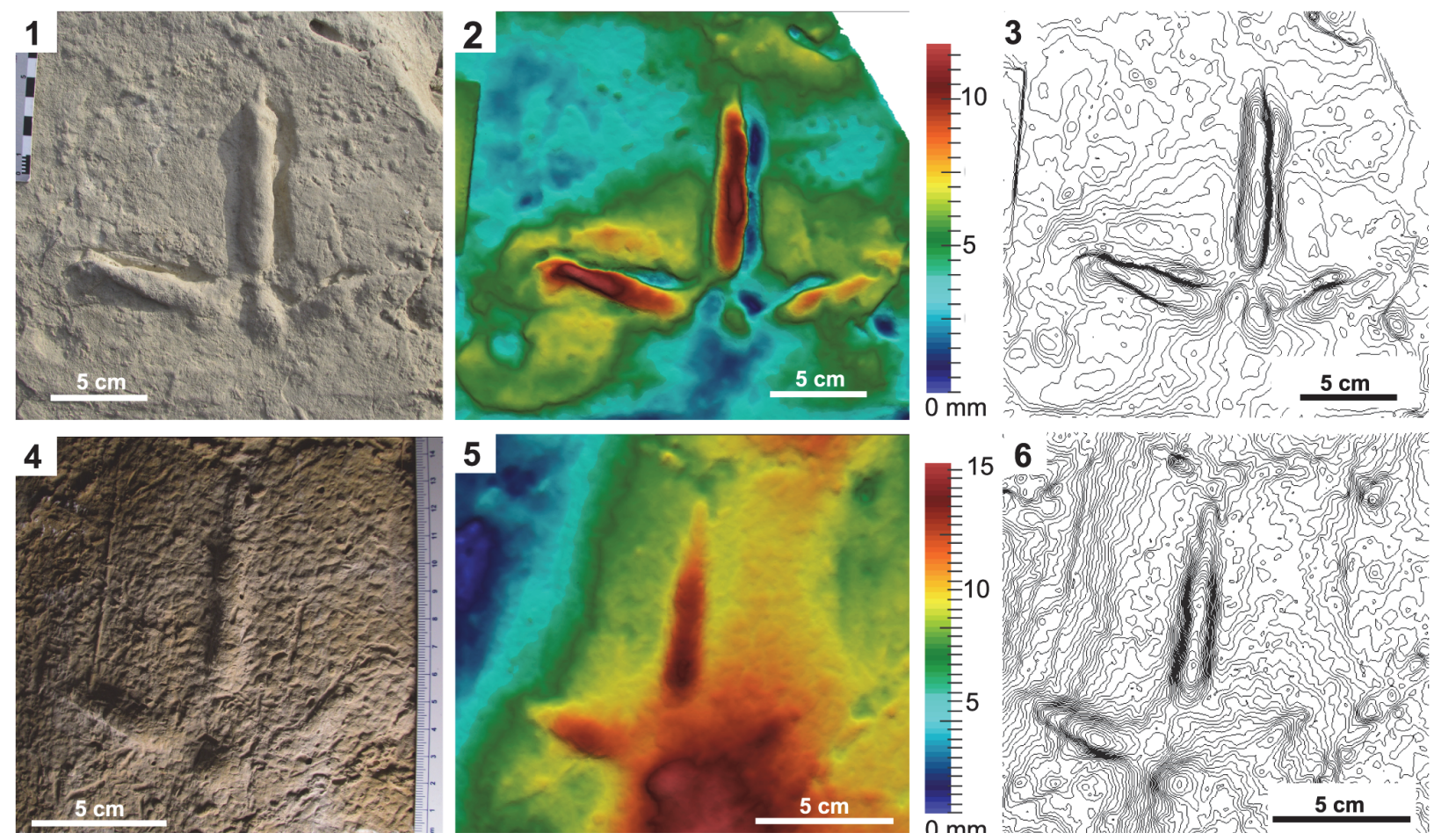

FIGURE 3.1, Picture; 2, false-color depth map of the photogrammetric model; 3, contour lines map with $0.5 \mathrm{~mm}$ of equidistance of AG1-1 footprint. 4, Picture, 5, false-color depth map of the photogrammetric model; 6, contour lines map with $0.5 \mathrm{~mm}$ of equidistance of Uvaichnites riojana holotype.

footprints of Aguilares. For a complete systematic ichnology discussion of Uvaichnites and other related ichnotaxa see Díaz-Martínez et al. (2012, p. 467).

Uvaichnites riojana Díaz-Martínez, Hernández, García Fernández, Murelaga, and Pérez-Lorente, 2012

Figures 2.1-4, 3.1-3

Material. AG1-1, AG1-2, AG1-3, AG2-1.1, AG21.2, AG3-1.1, AG3-1.2, AG3-2, AG3-3, AG3-4, AG4-1, and AG4-2.

Horizon and Locality. Lerín Formation of Agenian age (lower Miocene), Aguilares, Comunidad de Bardenas Reales, Navarra.

Description. Tridactyl, leptodactyl (slender digits), mesaxonic and unwebbed footprints with forwardly directed digit impressions. They are very large to enormous (see parameters of the ichnotaxobases in Díaz-Martínez et al., 2011, table 5) from $120 \mathrm{~mm}$ to $140 \mathrm{~mm}$ (average $130 \mathrm{~mm}$ ) long. The footprints are wider than long, wide from $156 \mathrm{~mm}$ to $190 \mathrm{~mm}$ (average $170 \mathrm{~mm}$ ). The central digit III impression is the longest (average $95 \mathrm{~mm}$ ). Digit II is shallower and smaller than IV (average $57 \mathrm{~mm}$ and $76 \mathrm{~mm}$, respectively). The digit divarication between digits II and IV is large and varies from $116^{\circ}$ to $150^{\circ}$ (average $131^{\circ}$ ). The footprints have angular asymmetry, average digit divarication between digits II and III is $62^{\circ}$ less than between III and IV which is $70^{\circ}$.

Digital pad impressions are recognizable in well-preserved footprints (AG1-1, AG1-2; Figure 3.1-3), digits II, III, and IV (2, 3, 2, respectively). They are often only slightly visible, although there are very clear bumps on the sole of the footprints marking the lateral outline of the pads (e.g., AG11). Digit impressions are slender and the proximal ends are not in contact with each other, even though they are sometimes very close to the central pad impression. The proximal part of digit III usually start more forward than digits II and IV proximal surface. The central pad impression is as long as wide average $(25 \mathrm{~mm} \times 25 \mathrm{~mm})$. The best preserved one, footprint AG1-1, presents a wide proximal surface and a narrower distal part. In some tracks (AG1-1, AG1-2, AG4-1) very well-preserved claw marks have been identified (more than $1 \mathrm{~cm}$ long). Claw marks are narrower than the digit impressions and present a very acuminate distal end (Figure. 4.1-3). The digit III claw mark is straight and digit claw marks II and IV are laterally curved. No evidence of webbed toes is preserved. 
The pace length of two pairs of footprints (AG2-1 and AG3-1) is $400 \mathrm{~mm}$ and $470 \mathrm{~mm}$, respectively.

\section{DISCUSSION}

\section{Systematic Ichnology Discussion}

The bird footprints studied in this work (Aguilares tracksite) are classified as Uvaichnites riojana because they share almost all their features with the original diagnosis of this ichnotaxon. For instance, the footprints of Aguilares and Uvaichnites type series (see Figures 3.1-4, 4.1-6) are of similar size (more than $100 \mathrm{~mm}$ ) mesaxonic tridactyl tracks with a prominent central pad impression and with digit impressions not jointed proximally. In both cases, the digit III impression is the longest followed by digit IV and digit II (III>IV >II). Although the tracks present different preservation, there is no evidence of hallux impression (digit I). The divergences between digits II and IV in all the footprints (Aguilares tracksite and Uvaichnites type series) are greater than $100^{\circ}$, and the angles between digits II and III are smaller than III and IV. Web traces are always absent in all the footprints. The footprints of Aguilares differ in three features from Uvaichnites original diagnosis. Aguilares footprints (e.g., AG1-1, AG1-2, AG4-1) present wellpreserved claw marks, whereas in the diagnosis of Uvaichnites Díaz-Martínez et al. (2012) affirmed that the claw marks are not well-defined (Figure 3.4-7). The claw marks in Aguilares tracks (digit III forwardly oriented and digits II and IV laterally curved; Figure 4.1-3), are also present in some extant crane birds (e.g., Grus leucogeranus Figure 4.4). Moreover, Díaz-Martínez et al. (2012) proposed in the diagnosis of Uvaichnites that the central digit length (III) is more than $25 \%$ longer than lateral digits. In Aguilares footprints, digit III length is more than $25 \%$ longer than digit II, but less than $25 \%$ longer than digit IV. Finally, in some footprints of Aguilares (e.g., AG1-1, AG2-1.2) two pad impressions have been identified in digit IV, whereas in the type series there have not been any pad preserved in this digit.

The presence in some Aguilares footprints of well-preserved claw marks, pad impressions in digit IV and long digit IV impressions is due to the fact that some (but not all, e.g., AG2-1.2, AG3-1.2, AG4-2) of these footprints are better-preserved than the holotype and paratypes of Uvaichnites (see Figure 3 for a comparison). With the aim of improving the original diagnosis of Uvaichnites riojana, we have emended it with new information (the three characters discussed above) coming from the better-preserved footprints of Aguilares. In addition to well-preserved footprints, other worse preserved ones are included, aiming for a bigger sample size and a better representation of the variability of this ichnotaxon. In some of them, the claws, the central pad, and digit II are not well impressed. If it is considered that all the footprints have the same main shape (probably impressed by the same kind of trackmaker), the variability in this shape could be explained as rheological and/or behavioral changes (e.g., Marty, 2008; Castanera et al., 2013; Belvedere and Mallison, 2014; Razzolini et al., 2014). The fact of finding well- and not so well-preserved footprints in the same outcrop is very useful for ichnotaxonomic discussions because it allows understanding each ichnotaxon as a whole.

Currently there are only two tracksites with Uvaichnites footprints, Cenicero as type locality and Aguilares, and both have been found in the lower Miocene of the western part of the Ebro Basin (Díaz-Martínez et al., 2012; in this work). In addition, two trackways of Uvaichnites-like footprints have been cited in Shigatse (southwest of the Tibet-Qinghai plateau, China) in the latest Oligocene-earliest Miocene Qiuwu Formation (Xing et al., 2013). Unfortunately, Xing et al. (2013) informed that the Shigatse tracksite was destroyed by road construction. Representative examples of well-preserved tracks were measured and traced, using thin paper film overlays, but no photographs were taken and no latex molds were made (Xing et al., 2013, figures 3,4$)$. These tracks are very similar to Uvaichnites. They are tridactyl with a prominent central pad and unjointed digits at the proximal end. The main difference between Shigatse footprints and Uvaichnites is in the interdigital span. While Uvaichnites footprints present always more than $100^{\circ}$ of interdigital span, Shigatse ones are very variable with values between $65^{\circ}$ to $95^{\circ}$. Although Xing et al. (2013, figure 5) suggested that these tracks are comparable to Ornithoformipes Patterson and Lockley, 2004 and Pavoformipes Lockley and Delgado, 2007, their features shows a clear affinity with Uvaichnites. Pavoformipes is tetradactyl and presents the digit impressions jointed at the proximal end, and Ornithoformipes has broad digit impressions and very robust heel impression. Due to the fact that these footprints were destroyed and it is not possible to reanalyze them, their classification is difficult. Accordingly, we have decided to be cautious and assigning these tracks to cf. Uvaichnites. 

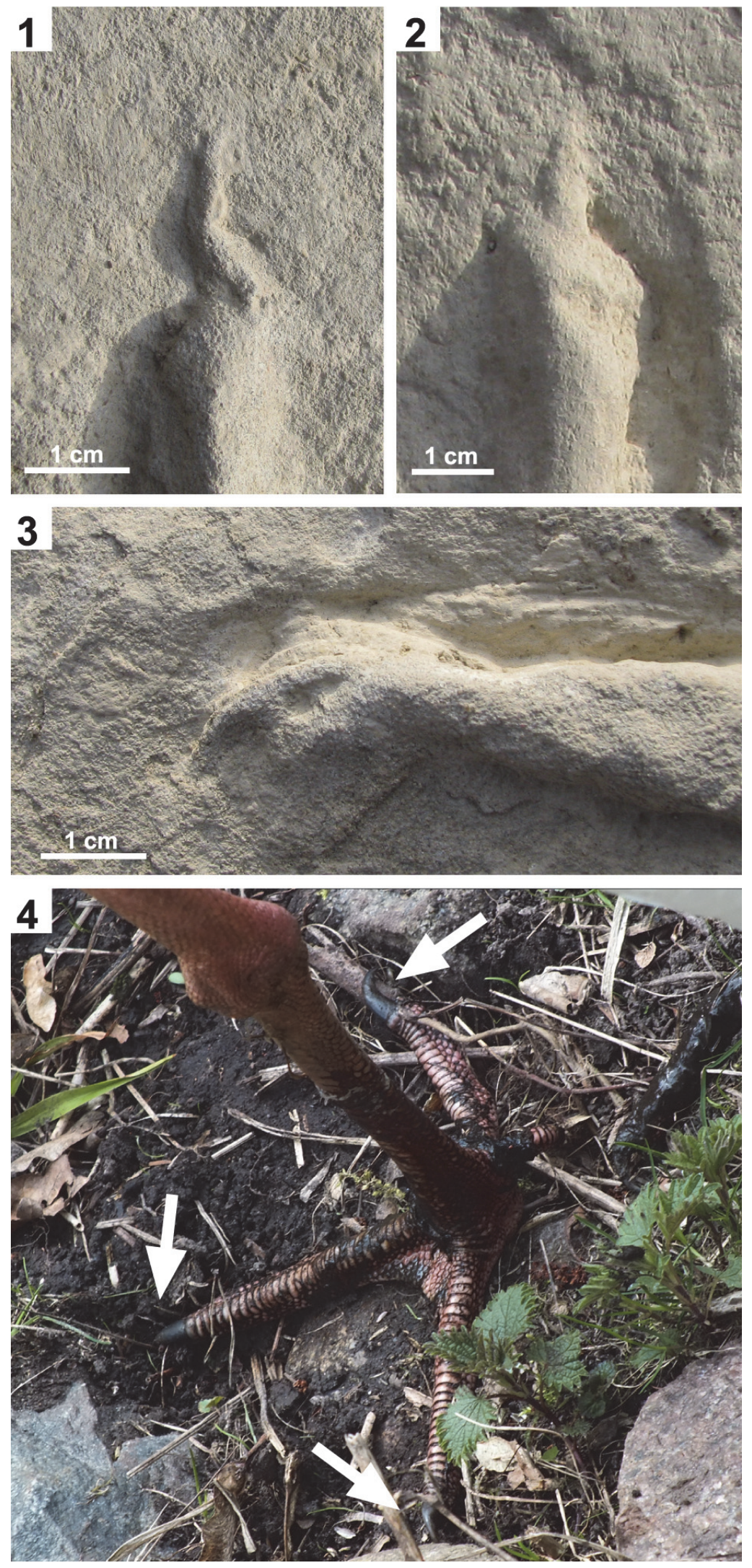

FIGURE 4. Detail of claw marks of Aguilares Uvaichnites riojana. 1, Digit III of AG1-1; 2, digit III of AG1-2; 3, digit IV of AG1-1; 4, Extant crane foot Grus leucogeranus. White arrows indicate the foot claws. 
Stratigraphic Distribution and Paleoenvironment of Uvaichnites-like Footprints

Uvaichnites riojana has been identified in two tracksites (Cenicero and Aguilares) in the western part of the Ebro Basin (Spain) (Díaz-Martínez et al., 2012; in this work) and some tracks found in the Qiuwu Formation (China) (Xing et al., 2013) have been classified in this paper as cf. Uvaichnites. The type series of Uvaichnites (Cenicero site) is preserved in a sandstone bed in the transition unit between the Nájera and Haro Formations, which accumulated in a mud-dominated, distal alluvial floodplain (Díaz-Martínez et al., 2011). According to their micromammal remains (see MartínezGarcía et al., 2015), the Cenicero site is situated in the Y2 local mammal zone of Daams and Van Der Meulen (1984), equivalent to the upper part of MN2 (European Neogene Land Mammal unit, Mein, 1999). Ruiz-Sánchez et al. (2012) considered that the age of this local zone is 19.9-20.05 Ma (Agenian, lower Miocene). As in Cenicero site, Aguilares tracks are preserved in a sandstone bed accumulated in a mud dominated, distal alluvial floodplain laterally associated with a saline lacustrine system. In Cabezo Marijuán section (see Figure 1) the Y2 local zone (upper part of MN2) has been located in Cuesta Agujeros 2 site, which is stratigraphically situated $120 \mathrm{~m}$ above of the sandstone blocks with footprints (Ruiz-Sanchez et al., 2012). Therefore, the Aguilares site is about 20.4 Ma old, approximately 0.4 Ma older than the Cenicero site. On the other hand, the Qiuwu Formation (China), where other Uvaichnites-like avian footprints have been found (Xing et al., 2013), was deposited during the latest Oligocene to the earliest Miocene (?23 Ma) according to the palynological data and detrital zircon U-Pb ages (Wang et al., 2013). This formation consists of sandstones and variously colored mud rocks that have been deposited in a lacustrine delta (Wang et al., 2013).

The three localities with bird footprints related with Uvaichnites are dated as latest Oligocene-earliest Miocene (from $\sim 23$ to $19.9 \mathrm{Ma}$ ), being the Ebro basin localities from approximately the same age (from 20.4 to $19.9 \mathrm{Ma}$ ). Díaz-Martínez et al. (2012) suggested that Uvaichnites size and shape is close to the current Grus grus (common crane) footprints. So, although these three localities present almost the same age, it is probably just a matter of time to find similar records for other Neogene successions.

Bird footprints have been normally related with the shorebird ichnofacies. It was defined as
Cretaceous-Cenozoic ichnocoenoses that reveal recurrent associations of tracks of wading shorebirds and invertebrate traces in the lake shoreline (Lockley et al., 1994). Doyle et al. (2000) suggested that although this ichnofacies was interpreted as a lacustrine ichnofacies, the footprints are associated with beaches, marine influenced lagoons, or other lake type. Even de Gibert and Saez (2009) considered that the shorebird ichnofacies characterizes the subaerial part of low-energy shore areas. In addition, these authors proposed that the shorebird ichnofacies is a subset of the Scoyenia ichnofacies (an ichnosubfacies sensu Melchor et al., 2006). Uvaichnites-like footprints have been found in similar continental environments (perilacustrine deltaic and distal alluvial systems) and in the type locality are related with invertebrate traces (Díaz-Martínez et al., 2012). Taking into account these data, we ascribe the three localities with Uvaichnites-like tracks to the shorebird ichnosubfacies (sensu Melchor et al., 2006) within the Scoyenia ichnofacies. Doyle et al. (2000) proposed that the trackmakers of the bird footprints that belong to this ichnosubfacies are Charadriiformes (waders and gulls), Anseriformes (ducks and geese), and Ciconiiformes (storks and herons). With this work, it is possible to increase this list including the footprints of some Gruiformes (cranes).

Although there are still a few sites with Uvaichnites-like footprints, it appears that this kind of tracks is related to a specific age and environment. New findings are necessary to assess whether the Uvaichnites-like footprints may have utility in ichnofacial or biochronological studies.

\section{Early Miocene Avian Diversity in the Iberian Peninsula}

The global track record is much more abundant than the skeletal record and provides data as reliable as those obtained from skeletal remains (Carrano and Wilson, 2001; Avanzini et al., 2011). This fact is also relevant in the early Miocene of Iberian Peninsula owing to the scarcity of localities with avian remains (Sánchez-Marco, 1995a, 1995b). Up to date, only 14 localities with avian remains have been found (see Table 2): nine with bones, four with footprints, and one with eggs and bones. For this analysis, we have divided the early Miocene in zones considering the European Neogene Land Mammal units (Mein, 1999), from MN1 to MN4 (23.03-15.97 Ma).

Astibia et al. (2007) cited the presence of bird footprints that probably come from the MN1-MN3 
TABLE 2. Avian fossil record from the early Miocene in the Iberian Peninsula. All the information is extracted from Sánchez-Marco (1999, 2006), Mlíkovský (2002), Grellet-Tinner et al. (2012), and Díaz-Martínez et al. (2015). Only the most recent taxonomic/ichnotaxonomic determination is considered.

\begin{tabular}{lccc}
\hline \multicolumn{1}{c}{ Taxon/ichnotaxon } & Zone & Locality (province) & Reference \\
\hline Koreanaornis isp. & MN 1- MN 3 & Los Arcos (Navarra) & Díaz-Martínez et al. (2015) \\
Aves indet. & MN 2 & Navarrete (Teruel) & Adrover (1975) \\
Gruipeda cf. máxima & MN 2 & Cenicero (La Rioja) & Díaz-Martínez et al. (2011) \\
Uvaichnites riojana & MN 2 & Cenicero (La Rioja) & Díaz-Martínez et al. (2012) \\
Koreanaornis isp. & MN 2 & Cenicero (La Rioja) & Díaz-Martínez et al. (2015) \\
Uvaichnites riojana & MN 2 & Aguilares (Navarra) & In this work \\
Plesiocathartes? gaillardi & MN 3 & El Fallol (Barcelona) & Crusafont and Villalta (1955) \\
Phoenicopteridae indet. & MN 3 & Bardenas Reales (Navarra) & Murelaga (2000) \\
Phoenicopteridae indet. & MN 3 & Bardenas Reales (Navarra) & Grellet-Tinner et al. (2012) \\
Palaeortyx edwardsi & MN 4 & Can Mas (Barcelona) & Villalta (1963) \\
Miophasianus altus & MN 4 & Can Mas (Barcelona) & Sánchez-Marco (2006) \\
Aves indet. & MN 4 & Alto de Ballester (Teruel) & Sánchez-Marco (1999) \\
Aves indet. & MN 4 & La Retama (Cuenca) & Sánchez-Marco (1999) \\
Aves indet. & MN 4 & Estación Imperial (Madrid) & Sánchez-Marco (1999) \\
Aves indet. & MN 4 & La Artesilla (Zaragoza) & Sánchez-Marco (1999) \\
Miophasianus sp. & MN 4 & Córcoles (Guadalajara) & Alférez et al. (1982) \\
Aves indet. & MN 4 & Els Casots (Barcelona) & Sánchez-Marco (1999) \\
Large bird tracks & MN 4- MN6 & Salinas de Añana (Álava) & Antón et al. (1993) \\
Small bird tracks & MN 4- MN6 & Salinas de Añana (Álava) & Antón et al. (1993) \\
\hline
\end{tabular}

zone taking into account their stratigraphic position. They classified these footprints as Charaadriipeda ispp., but Díaz-Martínez et al. (2015) considered them as Koreanaornis isp. This type of footprint, labelled as a shorebird-like footprint, has been related with Charadriiformes trackmakers (Doyle et al., 2000; Díaz-Martínez et al., 2015).

The information of the MN2 zone is almost exclusively given by footprints. There is only one citation of skeletal remains that is not very informative (determined as Aves indet. sensu Adrover, 1975). The avian footprints were classified as Gruipeda cf. maxima, Uvaichnites riojana, and Koreanaornis isp. and they have been related with herons (Ardeidae), cranes (Gruidae), and sandpipers (Charadriiformes), respectively (see DíazMartínez et al., 2011, 2012, 2015; and references therein).

Skeletal and oological remains have been found in the MN3 zone of the Iberian Peninsula. Crusafont and de Villalta (1955) defined the species Plesiocathartes? gaillardi and described it in the family Cathartidae (New World vultures). However, Mlíkovský (2002) affirmed that important differences from vulturids were mentioned in the description, and he relegated this taxon to the Aves incertae sedis until its holotype is located and restudied. In other locality, bones and eggs were found and were assigned to Phoenicopteridae indeterminate (Murelaga, 2000; Grellet-Tinner et al., 2012).

There are some localities in the MN4 zone with avian remains, but some of them hardly give information (Sánchez-Marco, 1999), which is the case of four of the localities where the bones were classified as Aves indet. (Sánchez-Marco, 1999). In two other localities, the presence of Palaeortyx edwardsi, Miophasianus altus, and Miophasianus sp. (De Villalta, 1963; Sánchez-Marco, 1999, 2006) has been cited. These taxa were related with the family Phasianidae (Mlíkovský, 2002; SánchezMarco, 2006). Finally, Antón et al. (1993) found some avian tracks in the MN4-MN6 (Antón et al., 2004), and they named them as large and small bird footprints.

The sum of the skelatal, oological, and ichnological record allows having a more complete vision of the avian diversity in the early Miocene in the Iberian Peninsula. The bone remains have been included within the families Phoenicopteridae, Phaisanidae, and Cathartidae (or incertae sedis sensu Mlíkovský, 2002), the eggs in the fam- 
ily Phoenicopteridae, and the footprints could be impressed by trackmakers related with Charadriiformes, Ardeidae, and Gruidae. Notably, the information provided by the footprints is important in this analysis. Freshwater and coastal birds (Phoenicopteridae, Charadriiformes, Ardeidae, and some Gruidae taxa) excel in this association, and almost all this information is obtained from the ichnological record. Nevertheless, the re-study of the skeletal record, especially the material classified as Aves indet., might possibly change this scenario.

\section{CONCLUSIONS}

A new tracksite, Aguilares, with bird footprints has been found in the Bardenas Reales de Navarra Natural Park (Navarra province, northwest sector of the Ebro Basin, Spain). The footprints are preserved in four slabs, come from the upper part of the Lerín Formation, and have an estimated age of 20.4 Ma (Agenian, lower Miocene). The footprints have been classified as Uvaichnites riojana because they display almost all the diagnostic features of this ichnotaxon. The best-preserved Aguilares footprints differ in three characters from Uvaichnites original diagnosis: presence of claw marks, pad impressions in digit IV, and long digit IV impressions. Some of these footprints are better preserved than the holotype and paratypes of Uvaichnites, so the original diagnosis has been emended with the novel information provided in this study. In addition, we have reassigned other bird footprints of the Quuwu Formation (China) as cf. Uvaichnites. The age and the environment of the three localities with Uvaichnites-like footprints (type locality, Aguilares and Quuwu Formation) are similar, so that new findings are needed to assess whether this kind of footprint could be useful in ichnofacial or biochronological studies. Few avian remains (bones, eggs and footprints) have been cited in the early Miocene of the Iberian Peninsula. The bird footprints could be impressed by trackmakers related with Charadriiformes, Ardeidae and Gruidae, while the bone and egg remains have been included within the families Phoenicopteridae, Phaisanidae and Cathartidae (or incertae sedis). The ichnological diversity shown in this paper throughout the early Miocene complements and improves the information about the avian diversity in the Iberian Peninsula at that time.

\section{ACKNOWLEDGEMENTS}

The authors thank the staff of the Comunidad de las Bardenas Reales de Navarra and A. Guallar
Resa for reporting the discovery of the tracks that has made this work possible. We thank X. PeredaSuberbiola (UPV/EHU) for comments on an early version of the manuscript, and two anonymous reviewers and K. Claeson (Handling Editor) for comments and suggestions that improved the manuscript. We also are grateful to $\mathrm{M}$. Belvedere (Museum für Naturkunde Berlin) for the crane photographs. This study was supported by the project GIU 12/35 of the University of Basque Country (UPV/EHU), a Ph.D. grant BFI-2012-118 (O. Suarez-Hernando) from the Basque Government, a postdoctoral grant "Contratación para la especialización de personal investigador doctor" (B. Martínez-García) from the UPV/EHU, and a postdoctoral grant from the Ministerio de Ciencia, Tecnología e Innovación Productiva Consejo Nacional de Investigaciones Científicas y Técnicas from Argentina (I. Díaz-Martínez).

\section{REFERENCES}

Adrover, R. 1975. Principales yacimientos paleomastológicos de la provincia de Temel y su posición estratigráfica relativa. Trabajos del Neógeno-Cuaternario, 4:31-48.

Alférez, F., Molero, G., Brea, P., and Santafé, J.V. 1982. Precisiones sobre la geología, fauna, cronoestratigrafía y paleoecología del yacimiento mioceno de Córcoles. Revista de la Academia de las Ciencias Exactas, Físicas y Naturales, 76:249-276.

Alonso-Zarza, A.M., Armenteros, A., Braga, J.C., Muñoz, A., Pujalte, V., Ramos, E., Aguirre, J., AlonsoGavilán, G., Arenas, C., Baceta, J.I., Carballeira, J., Calvo, J.P., Corrochano, A., Fornós, J.J., González, A., Luzón, A., Martín, J.M., Pardo, G., Payros, A., Pérez, A., Pomar, L., Rodríguez, J.M., and Villena, J. 2002. Tertiary, p. 293-334. In Gibbons W. and T. Moreno (eds.), The Geology of Spain. Geological Society, London.

Antón, M., López, G., and Santamaría, R. 1993. Observaciones preliminares sobre la locomoción de los carnívoros del Mioceno Inferior del yacimiento de Salinas de Añana (Álava). Temas Geológico-Mineros ITGE, 26:151-155.

Antón, M., López, G., and Santamaría, R. 2004. Carnivore trackways from the Miocene site of Salinas de Añana (Alava, Spain). Ichnos, 11:371-384.

Astibia, H., del Valle de Lersundi, J., and Murelaga, X. 1994. Icnitas de artiodáctilos (Mammalia) del Paleógeno de Olcoz (Depresión del Ebro, Navarra). Estudios Geológicos, 50:119-126.

Astibia, H., Pereda-Suberbiola, X., Payros, A., Murelaga, X., Berreteaga, A., Baceta, J. I., and Badiola, A. 2007. Bird and mammal footprints from the Tertiary of Navarre (Western Pyrenees). Ichnos, 14:175-184.

Avanzini, M., Bernardi, M., and Nicosia, U. 2011. The Permo-Triassic tetrapod faunal diversity in the Italian 
southern Alps, p. 591-608. In Dar, A. (ed.), Earth and Environmental Sciences. INTECH Open Access Publisher, Rijeka.

Belvedere, M. and Mallison, H. 2014. Metatarsal impression in modern ratites: gait, behaviour and posture influences. Journal of Vertebrate Paleontology, 89A.

Carrano, M.T. and Wilson, J.A. 2001. Taxon distributions and the tetrapod track record. Paleobiology, 27:564582.

Casanovas, M.L., Fernández, A., Pérez-Lorente, F., and Santafé Llopis, J.V. 1989. Huellas fósiles de dinosaurios de la Rioja. Yacimientos de Valdecevillo, La Senoba y de la Virgen del Campo. Ciencias de la Tierra, 12:1-190.

Castanera, D., Vila, B., Razzolini, N.L., Falkingham, P.L., Canudo, J.I., Manning, P.L., and Galobart, À. 2013. Manus track preservation bias as a key factor for assessing trackmaker identity and quadrupedalism in basal ornithopods. PLoS ONE, 8 (1):e54177.

Crusafont, M. and de Villalta, J.F. 1955. Parte Paleontológica. Apéndice 1. Aves, p. 236-237. In Crusafont, M., de Villalta J.F., and Truyols, J. (eds.), El Burdigaliense continental de la cuenca del VallésPenedés. Memorias y Comunicaciones del Instituto Geológico 12, Barcelona.

Daams, R. and Van der Meulen, A.J. 1984. Paleoenvironmental and paleoclimatic interpretation of micromammal faunal successions in the Upper Oligocene and Miocene of north central Spain. Paléobiologie continentale, 14:241-257.

De Gibert, J.M. and Saez, A. 2009. Paleohydrological significance of trace fossil distribution in Oligocene fluvial-fan-to-lacustrine systems of the Ebro Basin, Spain. Palaeogeography, Palaeoclimatology, Palaeoecology, 272:162-175.

De Valais, S. and Melchor, R.N. 2008. Ichnotaxonomy of bird-like footprints: an example from the Late Triassic-Early Jurassic of Northwestern Argentina. Journal of Vertebrate Paleontology, 28:145-159.

De Villalta, J.F. 1963. Las aves fósiles del Mioceno español. Boletín de la Real Sociedad Española de Historia Natural, 61:263-285.

Díaz-Martínez, I., García Fernández, S., Hernández, J.M., Murelaga, X., and Pérez-Lorente, F. 2011. Icnitas de aves y mamíferos del Mioceno inferior de La Rioja (Cuenca del Ebro, España). Ameghiniana, 48:139-153.

Díaz-Martínez, I., Hernández, J.M., Fernández, S.G., Murelaga, X., and Pérez-Lorente, F. 2012. Uvaichnites riojana: A new crane-like bird ichnotaxon from the lower Miocene of La Rioja (Ebro Basin, Spain). Proceedings of the Geologists' Association, 123:464470.

Díaz-Martínez, I., Suarez-Hernando, O., Martinez-Garcia, B., Hernández, J.M., Fernández, S.G., PerezLorente, F., and Murelaga, X. 2015. Early Miocene shorebird-like footprints from the Ebro Basin, La Rioja, Spain: paleoecological and paleoenvironmental significance. Palaios, 30:424-431.
Doyle, P., Wood, J.L., and George, G.T. 2000. The shorebird ichnofacies: an example from the Miocene of southern Spain. Geological Magazine, 137:517-536.

Falkingham, P.L. 2012. Acquisition of high resolution three-dimensional models using free, open-source, photogrammetric software. Palaeontologia Electronica, 15.1.1T:15p; palaeo-electronica.org/content/93issue-1-2012-technical-articles/92-3d-photogrammetry.

García-Raguel, M., Cuevas-González, I., Díaz-Martínez, I., and Pérez-Lorente, F., 2009. Fragmentos de roca con huellas de aves en el Terciario de Alcanadre (La Rioja). Descripción estructuras y problemas de identificación. Zubía, 27:1-78.

Grellet-Tinner, G., Murelaga, X., Larrasoaña, J.C., Silveira, L.F., Olivares, M., Ortega, L.A., Trimby, P.W., and Pascual, A. 2012. The first occurrence in the fossil record of an aquatic avian twig-nest with Phoenicopteriformes eggs: evolutionary implications. PLOS ONE, 7 (10):e46972.

Ingles, M., Salvany, J.M., Munoz, A., and Pérez, A. 1998. Relationship of mineralogy to depositional environments in the non-marine Tertiary mudstones of the southwestern Ebro Basin (Spain). Sedimentary Geology, 116:159-176.

Larrasoaña, J.C., Murelaga, X., and Garcés, M. 2006. Magnetobiochronology of Lower Miocene (Ramblian) continental sediments from the Tudela formation (western Ebro basin, Spain). Earth and Planetary Science Letters, 243:409-423.

Lockley, M.G. and Delgado, C.R. 2007. Tracking an ancient turkey: a preliminary report on a new Miocene ichnofauna from near Durango, Mexico. Bulletin of the New Mexico Museum of Natural History and Science, 42:67-72.

Lockley, M.G., Hunt, A., and Meyer, C. 1994. Vertebrate tracks and the ichnofacies concept: implications for palaeoecology and palichnostratigraphy, p. 241-268. In Donovan, S.K. (ed.), The Paleobiology of Trace Fossils. John Wiley and Sons, Chichester.

López, G., Mayoral, E., Muñoz, A., Pérez, A., and Santamaria, R. 1992. Nuevas icnitas de mamíferos carnívoros en el Mioceno inferior del sector occidental de la depresión del Ebro (Logroño, La Rioja). Revista de la Sociedad Geológica de España, 5:1-2.

Lourens, L.J., Hilgen, F.J., Laskar, J., Shackleton, N.J., and Wilson, D. 2004. The Neogene Period, p. 409440. In Gradstein, F.M., Ogg, J.G., and Smith A.G. (eds.), A Geologic Time Scale 2004. Cambridge University Press, Cambridge.

Mallison, H. and Wings, O. 2014. Photogrammetry in paleontology - a practical guide. Journal of Paleontological Techniques, 12:1-31.

Martínez-García, B., Suarez-Hernando, O., Hernández, J.M., Suárez-Bilbao, A., and Murelaga, X. 2015. Análisis paleoambiental de los depósitos aluviales de la sección de Cenicero a partir de las asociaciones de ostrácodos (Mioceno inferior, NO de la Cuenca del Ebro). Estudios Geológicos, 71:e024. 
Marty, D. 2008. Sedimentology, taphonomy, and ichnology of Late Jurassic dinosaur tracks from the Jura carbonate platform (Chevenez-Combe Ronde tracksite, NW Switzerland): insights into the tidal-flat palaeoenvironment and dinosaur diversity, locomotion, and palaeoecology. GeoFocus, 21:1-278.

Mein, P. 1999. European Miocene Mammal Biochronology, p. 25-38. In Rössner, G.E. and Heissig, K. (eds.), The Miocene Land Mammals of Europe. Verlag Dr. Friedrich Pfeil, München.

Melchor, R.N., Bedatou, E., De Valais, S., and Genise, J.F. 2006. Lithofacies distribution of invertebrate and vertebrate trace-fossil assemblages in an early Mesozoic ephemeral fluvio-lacustrine system from Argentina: implications for the Scoyenia ichnofacies. Palaeogeography, Palaeoclimatology, Palaeoecology, 239:253-285

Mlíkovský, J. 2002. Cenozoic Birds of the World. Part 1: Europe. Ninox Press, Praha.

Muñoz-Jiménez, A. and Casas-Sainz, A. 1997. The Rioja Trough (N Spain): tectosedimentary evolution of a symmetric foreland basin. Basin Research, 9:6585.

Murelaga, X. 2000. Estudio de las faunas de vertebrados del Mioceno inferior de las Bardenas Reales y áreas colindantes (Cuenca del Ebro, Navarra). Unpublished PhD Thesis, Universidad del País Vasco UPV/ EHU, Bilbao, Spain.

Murelaga, X., Astibia, H., Baceta, J.I., Almar, Y., Beamud, B., and Larrasoaña, J.C. 2007. Fósiles de pisadas de aves en el Oligoceno de Etaio (Navarra, Cuenca del Ebro). Geogaceta, 41:147-150.

Murelaga, X., Baceta, J.I., Astibia, H., Badiola, A., and Pereda Suberbiola, X. 2000. Icnitas de perisodáctilos en el Oligoceno de Navarra: posición estratigráfica y sistemática. Geogaceta, 27:15-17.

Patterson, J. and Lockley, M.G. 2004. A probable Diatryma track from the Eocene of Washington: an intriguing case of controversy and skepticism. Ichnos, 11:341-347.

Payros, A., Astibia, H., Cearreta, A., Pereda-Suberbiola, X., Murelaga, X., and Badiola, A. 2000. The Upper Eocene South Pyrenean coastal deposits (Liedena Sandstone, Navarre): sedimentary facies, benthic foraminifera and avian ichnology. Facies, 42:107132.
Pérez-Lorente, F. 2001. Paleoicnología. Los dinosaurios y sus huellas en La Rioja. Fundación Patrimonio Paleontológico de La Rioja, La Rioja.

Razzolini, N.L., Vila, B., Castanera, D., Falkingham, P.L., Barco, J.L., Canudo, J.I., Manning, P.L., and Galobart, À. 2014. Intra-trackway morphological variations due to substrate consistency: The El Frontal dinosaur tracksite (Lower Cretaceous, Spain). PloS ONE, 9 (4):e93708.

Ruiz-Sánchez, F.J., Murelaga, X., Freudenthal, M., Larrasoaña J.C., Furió, M., Garcés, M., González-Pardos, M., and Suarez-Hernando, O. 2012. Rodents and insectivores from the Lower Miocene (Agenian and Ramblian) of the Tudela Formation (Ebro Basin, Spain). Journal of Iberian Geology, 38:349-372.

Sánchez-Marco, A. 1995a. Tertiary avian localities of Portugal, p. 699-701. In Mlikovsky, J. (ed.), Tertiary Avian Localities of Europe. Acta Universitatis Carolinae Geologica 39. Universita Karlova, Praha.

Sánchez-Marco, A. 1995b. Tertiary avian localities of Spain, p. 719-732. In Mlikovsky, J. (ed.), Tertiary avian localities of Europe. Acta Universitatis Carolinae Geologica 39. Universita Karlova, Praha.

Sánchez-Marco, A. 1999. Catálogo paleornitológico del Terciario ibérico y balear. Estudios Geológicos, 55:163-171.

Sánchez-Marco, A. 2006. Miophasianus and Palaeoperdix (Galliformes, Aves) from three Miocene localities of Spain. Estudios Geológicos, 62 (1):249-256.

Villena, J., Pardo, G., Pérez, A., Muñoz, A., and González, A. 1996. The Tertiary of the Iberian margin of the Ebro basin: paleogeography and tectonic control, p. 86-88. In Friend, P.F., and Dabrio, C.J. (eds.), Tertiary Basins of Spain. Cambridge University Press, Cambridge.

Wang, J.G., Hu, X.M., Garzanti, E., and Wu, F.Y. 2013. Upper Oligocene-Lower Miocene Gangrinboche Conglomerate in the Xigaze area, southern Tibet: Implications for Himalayan uplift and paleo-YarlungZangbo initiation. The Journal of Geology, 121:425444.

Xing, L., Lockley, M.G., and Falk, A. 2013. First record of Cenozoic bird footprints from East Asia (Tibet, China). Ichnos, 20:19-23. 


\section{APPENDIX}

APPENDIX 1. Photogrammetric 3D models of the tracks AG1-1 of Aguilares tracksite (Navarre, Spain) (the .ply file is available in zipped format on the website palaeo-electronica.org/content/ 2016/1417-early-miocene-bird-footprints).

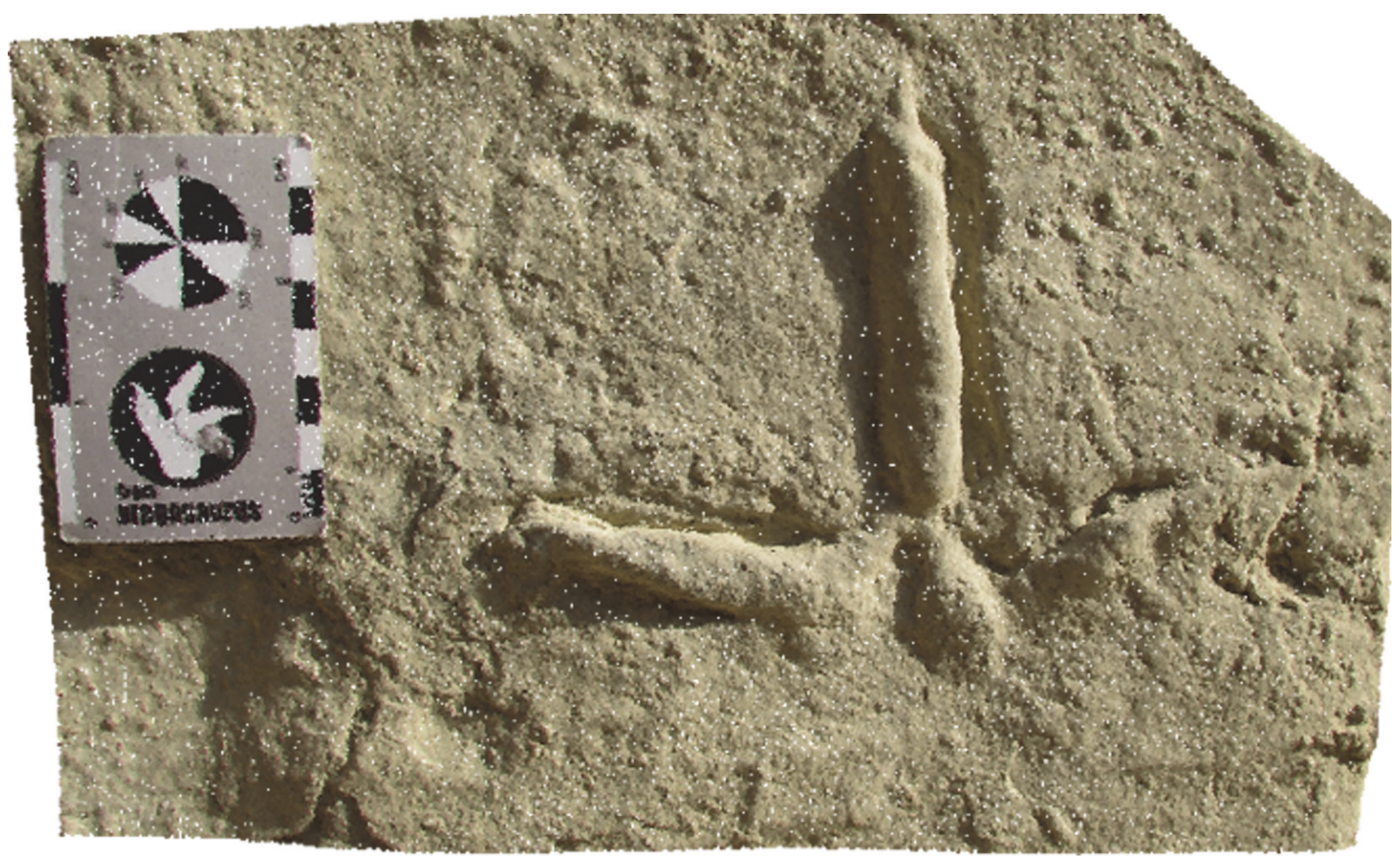


APPENDIX 2. Photogrammetric 3D models of the Uvaichnites riojana holotype of Cenicero tracksite (La Rioja, Spain) (the .ply file is available in zipped format on the website palaeo-electronica.org/content/2016/1417-early-miocene-bird-footprints).

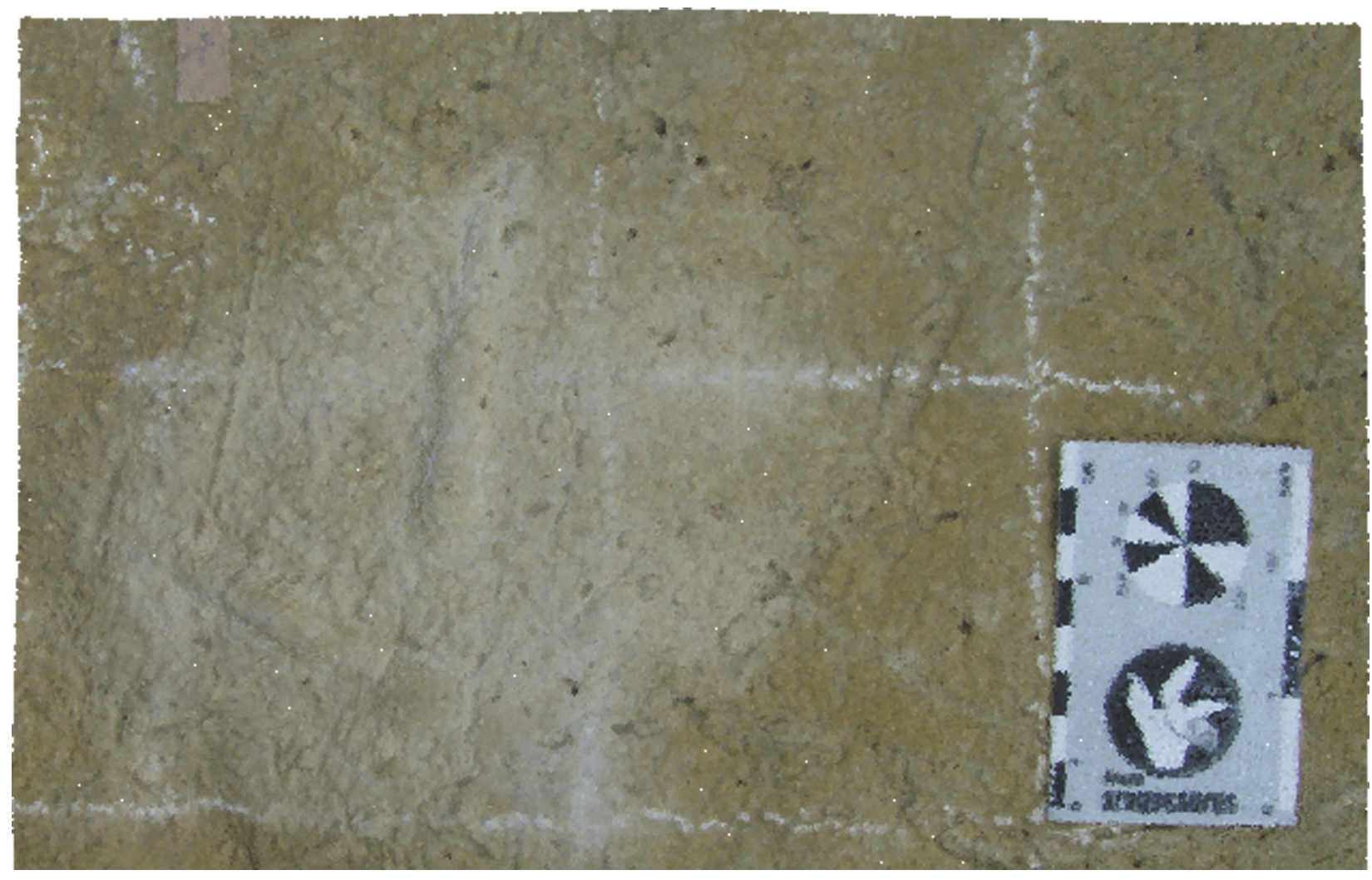

